\title{
Historical origins of the insanity defense in Sri Lanka and India
}

LA de Alwis

\section{Abstract}

In Sri Lanka, the legislative requirements of the insanity defense are contained within its Penal Code. Wording of this section is identical to the original version of the Indian Penal Code enacted in 1860 by the colonial British administration of India. The Sri Lankan Penal Code was based on the Indian Penal Code with changes to meet local requirements. Similarly, in many countries whose criminal codices were based on the Indian Penal Code, the insanity defense remains identical to that of Sri Lanka and India. While it has been suggested that the provisions for the insanity defense in Sri Lanka is based on the M'Naghten rules, no proper exploration has been done on how the law became to what it is now. This article reviews historical documents and secondary sources to trace the origin of the insanity defense in Sri Lanka and India.

SL J Psychiatry 2019; 10(2): 4-10

\section{Introduction}

Since the time of the Greek philosopher Plato (427-347 $\mathrm{BC})$, mental illness has been considered grounds for mitigation as well as exoneration of responsibility for criminal behaviour (1). In Sri Lanka and India, the legislative requirements for exculpation from responsibility for criminal acts based on mental illness are contained within criminal codes of the two countries. Section 77 of the Penal Code of Sri Lanka and Section 84 of the Indian Penal Code provide for the insanity defense. These two sections are identical in their phraseology: Nothing is an offence which is done by a person who, at the time of doing it, by reason of unsoundness of mind, is incapable of knowing the nature of the act, or that he is doing what is either wrong or contrary to law $(2,3)$. Wording of these two sections have remained unchanged from the original version of the Indian Penal Code enacted in 1860 by the colonial British administration of India. It can be reasonably surmised that the wording that forms the insanity defense in Sri Lanka originated in the Indian Penal code of 1860 given that the Sri Lanka (then Ceylon) Penal Code was based on the Indian Penal Code with changes to meet local requirements (4).
This article attempts to explore the historical origins of the insanity defenses of the two countries. Whist it has been suggested that the provisions for the insanity defense in Sri Lanka is based on the M'Naghten rules, no proper exploration has been done on how the law became to what it is now (5). The insanity defense in the Indian Penal Code has received much more scholarly attention compared to the Penal Code of Sri Lanka. Wherever possible I have referred to the primary sources, in tracing the origins of the insanity defense. However, much of the content in this article has been informed by the excellent review by Fergusan (2011) on the topic of insanity in the Indian Penal Code (6).

The Indian Penal Code being the first instance of codification of the criminal law in the British Empire, was adopted by many countries of the Commonwealth. Thus, in many countries, other than Sri Lanka, the origin of the insanity defense lies in Section 84 of the Indian Penal Code. It is remarkable and sobering to contemplate that despite over one and half centuries passing since it was enacted, the wording of the insanity defense in most of these countries remain identical to the 1860 version (Table 1). Whether this reflects the excellence of the original formulation of the defense or legislative apathy, is open for debate. 


\section{The Origins of the Indian Penal Code}

The first Indian Penal Code was the drafted by the inaugural Indian Law Commission appointed in 1834 under the Charter Act of 1833 by the Governor-General of India. This first draft of the commission submitted in 1837, is considered to be the work of Lord Macaulay, who was driven by utilitarian principles and was influenced by the ideas of the Jurist and English philosopher Jeremy Benthem. Even before sailing to India to become the legal member of the Legislative Council in India, Lord Macauley appears to have had a strong belief that India was in need of a criminal code (7). Even though some of his notions about India were clearly wrong, the code he created was light years ahead to what was available anywhere else in the British empire including England $(6,8)$.

\section{Section 66 and 67 of the first draft of the Indian Penal Code of 1837}

Lord Macauley stated, in the introduction to the first draft of the Indian Penal Code, that their draft legislature was not based on any existing law in India (Hindu or Mohammaden Law). Instead they had decided to seek guidance from the English common law, the French Penal Code of 1810 and the Penal Code of Louisiana of 1826 (9). This influence is evident in the provisions for acquittal on grounds of insanity, Section 66 and 67.

Section 66 stated; 'Nothing is an offence which is done by a person in a state of idiocy (sic)' and section 67 stated; 'Nothing is an offence which is done by a person in consequence of being mad or delirious at the time of doing it'. These were the first instances of provisions within written law in the British Empire for the insanity defense. Section 67 clearly draws from Article 64 of the French Penal Code of 1810, which provides: 'There is no crime of offence when the accused was in a state of madness (demence) at the time of the act ...' and from Article 35 of Livingston's draft Penal Code of Louisiana: 'No act done by a person in state of insanity can be punished as an offence'. This position was also in line with the English common law at that time, which considered 'lunatics and idiots' not chargeable for the acts, if committed 'while under these incapacities' (10).

Another source that Lord Macaulay may have drawn from to fashion section 67 was the case of $\mathrm{R} v$ Hadfield (1800). In this case the defense council Thomas Erskin told the jury: 'I must convince you, not only that the prisoner was lunatic, but that the act in question was the immediate and unqualified offspring of the disease' (11). Erskin recommended the exculpation of the responsibility if the courts were convinced that the criminal act was the direct result of the mental illness. This case clearly differed from previous cases in which acquittal was based on the defendant's lack of capacity to distinguish between good and evil due to mental illness (12). The Hadfield case was considered an instance when the legal thinking on insanity moved from the antiquated notion of lack of memory and understanding to a more scientific and compassionate standard $(13,14)$.

In 1837 , Section 67 can be considered to have been ahead of its time as it not only explicitly stated that the criminal act be the 'product' of the madness, but also emphasized the need for the madness or delirium to exist at the time of the offence, which many of the existing the statues the Indian Penal Code was based on did not specify. However, after the M'Naghton Rules were established (in 1843) as the standard test for insanity, Section 67 was viewed as being too lenient. John Mayne writing in 1896 hypothesized that the Commissioners in 1837 had whole heartedly accepted the proposition made by Erskin, when they drafted section 67 and had granted 'a lunatic an immunity extending as far as anything claimed by medical theorist'.

Unlike many other sections in the code, the commissioners failed to provide any explanations or illustrations for Section 66 and 67. Moreover, these sections were not commented upon by any of the authorities the draft code was sent to for comment and criticism. This is indicative that none of the legal scholars at the time considered the provisions too liberal. The draft Indian Penal code was never enacted due to various geopolitical reasons. In the subsequent versions of the Indian Penal Code, the thinking behind the insanity defense changed completely to what Lord Macauley conceptualized in his original draft.

\section{The McNaughton trial and development of the M'Naghton Rules}

Daniel McNaughton suffered from a delusion in which he believed that he was being persecuted by spies of the Catholic church with the help of the Tories. He believed that he was being followed everywhere he went, and that would be eventually be murdered by his persecutors. He had complained to the police without any success. On the $20^{\text {th }}$ of June 1843, McNaughton shot Edward Drummond (the private secretary of the prime minister of England, Sir Robert Peel) believing him to be one of his persecutors. Edward Drummond died five days later, and Daniel McNaughton was charged with willful murder (15).

Daniel McNaughton was examined by no fewer than eight experts prior to the trial. The defense was led by the noted barrister Sir Alexander Cockburn. Through expert testimony and through the extensive use of Sir Isaac Ray's Treatise on the Medical Jurisprudence of Insanity (published in 1838), Cockburn argued that his client had lost all self-control at the time of committing the offence and that his act had flowed immediately from the delusion he held. It was presented to court that McNaughton had reached a critical level of being overwhelmed by his delusions that nothing short of a physical impediment would have prevented him from committing the crime. 
The verdict of the case was announced by the Jury to be one of 'not guilty, on the ground of insanity.' The verdict sparked much resentment in the public as well as in reigning Monarch, Queen Victoria. As a result, the House of Lords asked five questions related to the determination of the insanity in matters of criminal responsibility from the twelve judges of the Queen's Bench. The judges answered these questions with four principles which became known as the 'M'Naghton Rules'. These rules were accepted without any alteration by the House of Lords. With that the M'Naghton Rules crystalized the test for insanity in issues of criminal responsibility, in England and later in all of its domains.

To establish a defense of insanity in accordance with the M'Naghton Rules, the defense had to show that the accused, at the time of committing the act, the part accused was laboring under such defect of reason, from disease of mind, as not to know the nature and quality of the act he was doing; or if he did know it, that he did not know what he was doing was wrong.

What the judges were asked to do was quite unusual. In elucidating the M'Naghton Rules the judges were putting in place principles which would be the basis of the legislature on insanity in the absence of a specific case. The factors that were considered were hypothetical and did not concern the case of Daniel McNaughton (as he had already been tried). Nevertheless, it would be just to surmise that the case would have been at the top of minds of the all judges. Resulting rules, placed heavy emphasis of the intellectual understanding of the act (knowing the nature and knowing right from wrong), even though in the M'Naughton case this aspect was clearly avoided by the defense council. Instead, the defense had relied on an omnibus defense, highlighting the irresistible nature of the insanity, the overwhelming nature of the delusion and the how the act was direct result of his abnormal mental state. In direct contrast to the approach by the defense, the prosecution relied on the legal doctrines of Sir Mathew Hale on insanity, which stated the legal test in cases pertaining to insanity was one of understanding (13). The defense council Cockburn successfully reasoned that this doctrine of Sir Mathew Hale was antiquated and argued for acquittal based and more modern conceptualizations of responsibility. However, the M'Naghton Rules turned back the progress made in the McNaughton trail and firmly set the insanity defense back in the $18^{\text {th }}$ century concept of understanding.

Following the McNaughton rules in 1843, the only possible insanity defense that could have ended up in the Indian Penal Code was one based on the intellectual understanding of the offence.

In addition to the M'Naghton rules of 1843, the final version of the insanity defense of the Indian Penal Code is assumed to have been influenced by two other sources;
Act IV of the Legislative Council of India (1849) and the reports of the English Criminal Law Commissioners in 1843 and 1846 (6).

\section{English Criminal Law Commissioner's Reports - 1843 and 1846}

While the colonial government was taking steps to codify the criminal law in India, a similar process was underway to produce a criminal code in England. In 1833, the English Criminal Law Commission was established for this purpose. This commission produced eight reports starting in 1836 (16). The Seventh Report (1843) contained a complete draft code of the substantive criminal law and was complemented in the Eighth Report (1846) by a draft code of criminal procedure. The seventh report (published in 1843, before the McNaughton rules were formally made public) contained the two-prong insanity test that appears to have made its way to the final Indian Penal Code of 1860. On the chapter on Preliminary Declarations, Article 1 stated: 'No person shall be criminally liable for any act who, at the time of such act, by reason of any disease, disorder, or delusion of mind, or of weakness or unripeness of understanding, is either unconscious of what he does, or unable to discern that what he does is wrong, and therefore, knows not that he offends against the laws of God and man. The same rule shall apply to an omission' $(17,18)$. The two arms of the insanity test as stated in Article 1, were one of not knowing the nature (unconscious of what he does) and other of not knowing what he does is morally wrong and contrary to the law (not knowing he offends against the laws of God and man). However, in the eighth report (1846) the test of insanity was narrowed down, basing it only on the incapacity of not knowing one's actions were contrary to the law of the land. It is note-worthy that the commissioners used the word 'unsoundness of mind' to describe the afflicted state of mind of the defendant in this report (19).

The Criminal Law Commissioners reports as well as the following English statures: Criminal Lunatics Act 1800 (39 and 40 Geo III. Cap. 94), Criminal Lunatics Act 1838 (1 and 2 Vict. Cap 14); and An Act for the making further Provisions for the Confinement and Maintenance of Insane Prisoners 1840 (4 Vict. Cap 54) appears to have influenced the content of Act IV of the Legislative Council of India 1849(20).

\section{Act IV of the Legislative Council of India 1849}

The Indian Legislative Council passed 'An Act for the Safe Custody of Criminal Lunatics in 1849 (Act IV of 1849). In addition to providing the legal framework for the safe custody or detention of mentally ill persons guilty of criminal acts, the act recognized insanity as grounds for acquittal in criminal matters. This Act is considered by experts to be the work of John Elliot Drinkwater Bethune, an Anglo-Indian lawyer, who was appointed as a law member of the Governor Generals Council in 1848 (6). 
In 1845, the Calcutta Court of Nizamat Adalat proposed the need for new statues to provide authority for the custody of those who have been acquitted on grounds of insanity until they had recovered from the derangement. In response to this proposal, Act IV of the 1849 was passed. Bethune writing in 1848 noted that the 'Regulations and Acts of India are wholly silent on the subject of lunatics charged with the commission of offences. The law as practically administered in England is far from being a clear and satisfactory state and I think that the Act which is called for by the Nizamet Adalat, should not only provide for the custody of such persons but should lay down a Rule for the guidance of the courts in their judgment of such cases'. Section 1 of Act IV codified the defense of insanity: 'No person can be acquitted for unsoundness of mind unless it can be proven that, by reason of unsoundness of mind, not willfully caused by himself, he was unconscious and incapable of knowing, in doing the act, that he was doing an act forbidden by the law of the land' (20). The wording of this legislature had much similarities to the wording of the legal test of insanity in the M'Naghton Rules as well as to the insanity defense proposed by the English Criminal Law Commissioners.

Despite the similarities, Bethune was skeptical about the need for a legal provision that provided an exception from culpability for those with mental illness. Bethune was of the view that the 'plea of lunacy would be wholly disallowed' and should be 'left to the prerogative of mercy to pardon those unhappy persons who alone really deserve exemption because they alone are really free from guilt' $(20,21)$. He was supported in this view by the governor-general, who believed that a defendant deserved to be punished for his actions as long as the person knew what he was doing was wrong, despite being urged to commit the crime due to mental illness (21). Despite these views at the highest level of Indian government, Act IV of 1849, legislated the provisions for an insanity defense into the statutes of India.

\section{Enactment of the Indian Penal Code}

The Indian Mutiny of 1857 and its aftermath prioritized the need for a uniform criminal code (22). After more than two decades of revisions and delays the Indian Penal Code was finally enacted as Act XLV in October 1860. The Indian Penal Code came into force on the $1 \mathrm{st}$ January 1862. This was first criminal code of the Commonwealth and was soon adopted by the British colonial authorities of Ceylon, the Straits Settlements, Singapore, Burma and Brunei. Subsequent to the partition of India, the Indian Penal Code was inherited first by Pakistan and later by Bangladesh. Despite multiple amendments done to the original criminal code, the insanity defense remains unchanged from how it was formulated in 1860 in all the countries which adopted the Indian Penal Code (Table 1).

\section{The term Unsound $M$ ind as used in the Indian Penal Code}

Legal texts written around the time the Indian Penal Code was enacted note that the existing English law considered the terms lunatic, idiot and unsound mind as having separate meanings. A person of unsound mind was considered an individual who 'by reason of a morbid condition of intellect' was unable to manage himself or his affairs, but not being 'an idiot, or a lunatic or a person of merely weak mind'. The term non compos mentis was the term that was being used to refer to any of the aforementioned categories (23). In his first draft of the Indian Penal Code, Macauley appears to have considered the terms 'idiocy' separate to those he considered 'mad or delirious'. Section 306 of the draft code (section on the punishment for abating suicide) indicates that the terms idiot, insane and the delirious have three separate meanings. These terms have neither been defined nor given any explanatory notes in the draft code or in the Indian Penal Code. The term unsound mind used in the IPC is considered to represent the term non compose mentis referring to all three legally recognized categories of mental defects. In a contemporary text book on the Indian Penal Code of 1860, the authors explained the ambit of the word unsound mind; Whether the want of capacity is temporary or permanent, natural or supervising, whether it arises from disease or exists from the time of birth, it is included in the expression "unsoundness of mind". Thus an idiot who is a person without understanding from his birth, a lunatic who has intervals of reason, and a person who is mad or delirious, are all persons of unsound mind (24). Considering that the 1837 draft provided complete exoneration from responsibility to those with idiocy as well as to those who were mad or delirious, combining the terms into a single concept in the final code would have been acceptable to Lord Macauley.

\section{Insanity defense in Ceylon before the passage of the Ceylon Penal Code}

There appears to be no codified legal tests for the insanity defense in Ceylon until the enactment of the Ceylon Penal Code in 1883. Statutes dealing with insanity for the purpose of guardianship was available in the country from 1801 with the introduction of the in the Royal Charter of Justice. Statues dealing with insanity for the purpose of civil commitment was introduced in 1839. The Lunacy Ordinance was enacted in 1873. Both the 1839 Ordinance and the 1873 Ordinance had provisions dealing with those who were acquitted on grounds of insanity from criminal charges $(25,26)$. Thus, despite the lack of a codified legal test, determinations of insanity would have been carried out in the Ceylon courts well before the passage of the Ceylon Penal Code. These determinations are likely to have been based on English Case Law. 


\begin{tabular}{|c|c|c|c|}
\hline Country & Criminal Code & $\begin{array}{l}\text { Last amendment } \\
\text { to the } \\
\text { Penal Code }\end{array}$ & $\begin{array}{l}\text { Section and wording of the insanity } \\
\text { defence }\end{array}$ \\
\hline India & $\begin{array}{l}\text { Indian Penal Code } \\
\text { (Act No XLV of 1860) }\end{array}$ & & $\begin{array}{l}\text { 84. Act of a person of unsound mind: } \\
\text { Nothing is an offence which is done by a } \\
\text { person who, at the time of doing it, by } \\
\text { reason of unsoundness of mind, is inca- } \\
\text { pable of knowing the nature of the act, or } \\
\text { that he is doing what is either wrong or } \\
\text { contrary to law. }\end{array}$ \\
\hline Pakistan & $\begin{array}{l}\text { Pakistan Penal Code } \\
\text { (Act No XLV of 1860) }\end{array}$ & 2002 & $\begin{array}{l}\text { 84. Act of a person of unsound mind: } \\
\text { Nothing is an offence which is done by a } \\
\text { person who, at the time of doing it, by } \\
\text { reason of unsoundness of mind, is inca- } \\
\text { pable of knowing the nature of the act, or } \\
\text { that he is doing what is either wrong or } \\
\text { contrary to law. }\end{array}$ \\
\hline Bangladesh & $\begin{array}{l}\text { The Penal Co de } \\
\text { (Act No XLV of 1860) }\end{array}$ & 2004 & $\begin{array}{l}\text { 84. Nothing is an offence which is done by } \\
\text { a person who, at the time of doing it, by } \\
\text { reason of unsoundness of mind, is inca- } \\
\text { pable of knowing the nature of the act, or } \\
\text { that he is doing what is either wrong or } \\
\text { contrary to law. }\end{array}$ \\
\hline Sri Lanka & $\begin{array}{l}\text { Ceylon Penal Code } \\
\text { (Ordinance } \\
\text { No. } 2 \text { of 1883) }\end{array}$ & 2006 & $\begin{array}{l}\text { 77. Nothing is an offence which is done by } \\
\text { a person who, at the time of doing it, by } \\
\text { reason of unsoundness of mind, is inca- } \\
\text { pable of knowing the nature of the act, or } \\
\text { that he is doing what is either wrong or } \\
\text { contrary to law. }\end{array}$ \\
\hline Singapore & $\begin{array}{l}\text { Penal Code } \\
\text { (Chapter } 24 \text { ) } \\
\text { (Ordinance } 4 \text { of 1871) }\end{array}$ & 2008 & $\begin{array}{l}\text { 84. Nothing is an offence which is done by } \\
\text { a person who, at the time of doing it, by } \\
\text { reason of unsoundness of mind, is inca- } \\
\text { pable of knowing the nature of the act, or } \\
\text { that he is doing what is either wrong or } \\
\text { contrary to law. }\end{array}$ \\
\hline Malaysia & Penal Code (Act 574) & 2015 & $\begin{array}{l}\text { 84. Nothing is an offence which is done by } \\
\text { a person who, at the time of doing it, by } \\
\text { reason of unsoundness of mind, is inca- } \\
\text { pable of knowing the nature of the act, or } \\
\text { that he is doing what is either wrong or } \\
\text { contrary to law. }\end{array}$ \\
\hline Brunei & $\begin{array}{l}\text { Chapter } 22 \\
\text { Penal Code } 16 \text { of } 1951\end{array}$ & 2019 & $\begin{array}{l}\text { 84. Nothing is an offence which is done by } \\
\text { a person who, at the time of doing it by } \\
\text { reason of unsoundness of mind, is } \\
\text { incapable of knowing the nature of the act, } \\
\text { or that he is doing what is either wrong or } \\
\text { contrary to law. }\end{array}$ \\
\hline Burma & $\begin{array}{l}\text { The Penal Code } \\
\text { (India Act XLV 1860) }\end{array}$ & & $\begin{array}{l}\text { 84. Nothing is an offence which is done } \\
\text { by a person who, at the time of doing } \\
\text { it, by reason of unsoundness of mind, is } \\
\text { incapable of knowing the nature of the act, } \\
\text { or that he is doing what is either wrong or } \\
\text { contrary to law. }\end{array}$ \\
\hline
\end{tabular}


The superintendent of the Colombo Lunatic Asylum, Dr JW Plaxton, writing in 1881, quoted the regulations of the Ceylon Lunatic Asylum to demonstrate how limited responsibility was placed on the criminal behaviours of the insane; 'It is only in comparatively rare cases - such as idiocy - that a person is wholly devoid of the power of self control and of the consciousness of wrong and, therefore, wholly free from legal and moral responsibility for criminal acts. In a very large proportion of cases insanity, as it is well known, is only recurrent or temporary, and not continuous; and is definitely limited to some special range of ideas or emotions;'. This regulations appears to be in line with the post McNaghton understanding of the criminal responsibility of the insane albeit highlighting that the majority of those in the Ceylon asylum did not meet the stringent criteria of such a test (27).

The legal test for the insanity defense was detailed in Section 72 in the Ceylon Penal Code, which used the exact same wording as in Section 84 of the Indian Penal Code. The wording remains unchanged in the modern Penal Code of Sri Lanka.

\section{Conclusion}

The insanity defense of Sri Lanka is identical to Section 84 of the Indian Penal Code. Similarly, in many other South Asian Countries, the codified insanity defense provisions are identical to that of the Indian Penal Code. Based on the M'naghton rules and influenced by the English and Indian Law commissioners the final form of the insanity defense that was included in the Indian Penal Code has withstood the test of time to remain unaltered from its original form in 1860 . In the ensuing century and a half, some Commonwealth countries have made changes to the insanity defense. These changes have included the insertion of the volitional prong in the test for insanity as well as recognition of diminished responsibility in place of the all-or-none insanity defense. Despite the changes, the essential elements of the insanity defense remain true to the original conception of the insanity test as codified in the Indian Penal Code. It is as if the shots that Daniel McNaghton fired on the afternoon of 20 January, 1843 are still echoing in the legal statutes of the 21 st century.

\section{Conflicts of interest}

None declared

$$
\begin{aligned}
& \text { LA de Alwis } \\
& \text { Corresponding author: LA de Alwis } \\
& \text { Email: angelo.dealwis@ gmail.com } \\
& \text { iD http://orcid.org/ 0000-0002-1101-7129 }
\end{aligned}
$$

\section{References}

1. Simon R, Ahn-Redding H. The Insanity Defense the World Over. (Global Perspectives on Social Issues). Plymouth: Rowman \& Littlefield; 2008. p. 3.

2. Section 77, SriLanka Penal Code (Ordinance No 2 of 1883).

3. Section 84, Indian Penal Code (Act XLV of 1860).

4. Nadaraja T. The Legal System of Ceylon in Its Historical Setting. (Asian Studies). Leiden: Brill; 1972. p. 232.

5. Peiris GL. General principles of criminal liability in Ceylon: a comparative analysis. Colombo: Lake House; 1972. p. 117.

6. Fergusan G. Insanity, In: Wright B, Chan WC. Yeo S (ed.) Codification, Macaulay and the Indian Penal Code: The Legacies and Modern Challenges of Criminal Law Reform. (International and Comparative Criminal Justice).Farnham: Ashgate 2011. p. 231-55.

7. House of Commons, Parliamentary Debates (3rd series) (10 July 1833) vol 19, at colls 531 and 533.

8. Skuy D. Macaulay and the Indian Penal Code of 1862: The Myth of the Inherent Superiority and Modernity of the English Legal System Compared to India's Legal System in the Nineteenth Century. Mod Asian Stud. 1998; 32(3): 513-57.

9. Indian Law Commissioners. A Penal Code Prepared by the Indian Law Commissioners, and Published by Command of the Governor General of India in Council [Internet]. Calcutta: Bengal Military Orphan Press, 1837. Available from: https://books.google.com.au/books?id =Q_pBAAAAYAAJ

10. Blackstone W, Sharswood G. Commentaries on the Laws of England, in Four Books. Philadelphia: JB Lippincott, 1893. Available from: https://books.google.com.au/ books?id= $\mathrm{xK} 0 \mathrm{mIjO} 2 \mathrm{E} 5 \mathrm{MC}$ (Accessed 8th August 2019)

11. R v. Hadfield (1800) 27 State Trials (new series) 1281.

12. R v. Arnold (1724) 16 How. St. Tr.765.

13. Hale M, Dogherty T, Emlyn S, Wilson G. Historia Placitorum Coronę: The History of the Pleas of the Crown. London: Little Britain, 1800.. Available from: https://books.google. com.au/books? id=2KoDAAAAQAAJ (Accessed 8th August 2019)

14. Ray I. A treatise on the medical jurisprudence of insanity. Boston: Little, Brown \& Co, 1871. Available from: https://books. google.com.au/books?id=sFwqJOhFrvgC (Accessed 8th August 2018)

15. Dalby JT. The case of Daniel McNaughton: let's get the story straight. Am J Forensic Psychiatry. 2006; 27(4): 17.

16. Bingham of Cornhill. Speech at Dinner for HM Judges, Speech presented at: The Mansion House, London 22 July 1998. London: Judiciary of England and Wales. Available at: https://web.archive.org/web/20070927120512/http:// www.judiciary.gov.uk/publications_media/speeches/ pre_2004/mnsion98.htm (Accessed on 8 Aug 2019)

17. Commissioners on Criminal Law. Seventh Report from His Majesty's Commissioners on Criminal Law. London: W Clowes \& Sons, 1843. 
18. Commissioners on Criminal Law. Report from His Majesty's Commissioners on Criminal Law. London: W Clowes \& Sons, 1834.

19. House of Commons. Irish University Press Series of British Parliamentary Papers: Legal Administration. Shannon: Irish University Press, 1971.

20. Banerjee TK. Background to Indian Criminal Law. Bombay: Orient Longmans, 1963.

21. Ernst W. Mad Tales from the Raj: Colonial Psychiatry in South Asia, 1800-58. Delhi: Anthem Press, 2010.

22. Kolsky E. Codification and the Rule of Colonial Difference: Criminal Procedure in British India. Law Hist Rev 2005; 23(3): 631-83.

23. Phillips CP. The Law Concerning Lunatics, Idiots, \& Persons of Unsound Mind. London: Butterworths, 1858.
24. Morgan W, Macpherson AG. The Indian Penal Code (Act XLV of 1860). Calcutta: GC Hay \& Co, 1863.

25. De Alwis LA. Development of civil commitment statutes (laws of involuntary detention and treatment) in Sri Lanka: a historical review. Medico-Legal J Sri Lanka 2017;5(1): 22-31.

26. Skeem W. A Collection of Legislative Acts of the Ceylon Government from 1796. Colombo: Government Printer

27. Plaxton JW. Criminal Insane in Ceylon. J Ment Sci. 1881; 27(117): 44-6. 